\title{
EFFECT OF SOIL PHYSICAL AND WATER STRESS ON BIOCHEMICAL ASPECTS OF COCONUT SEEDLINGS (Cocos nucifera L.) IN SRI LANKA
}

\author{
L.P. Vidhana Arachchi ${ }^{1}$, V.R.M. Vidhana Arachchi ${ }^{2}$ and E.S.P. Epasinghe ${ }^{3}$
}

\begin{abstract}
Soil physical and water stress conditions adversely affect the biochemical aspects of coconut production. Field experiments were conducted in Madampe and Andigama soil series, to investigate the ATPase activity, starch conversion to glucose and accumulation of proline in leaves, absorption cells and respiratory organs of coconut roots and their interrelationships with respect to soil physical and water stress. After one and half years of the establishment of coconut seedlings in different horizons of both series, the moisture contents at three depletion levels viz. $10 \mathrm{kPa}$ to $30 \mathrm{kPa}, 10 \mathrm{kPa}$ to $100 \mathrm{kPa}$ and $10 \mathrm{kPa}$ to $1500 \mathrm{kPa}$ were maintained using tensiometers and neutron scatteringtechnique in order to create moisture stress around root zone of coconut seedlings during the dry period. Detailed soil physical analysis showed that soil compaction limits the aeration and available water retention in soil horizons of both series. Evaluation of biochemical properties showed that the highest ATPase activity and starch conversion to glucose in leaves and absorption zone of coconut roots was observed in the $B$ horizon of Madampe series at field capacity moisture level (10 kPa to $30 \mathrm{kPa}$ suction), while the lowest activity was observed in the A horizon of Madampe series and B horizon of Andigama series at high water stress condition (100 kPa to $1500 \mathrm{kPa}$ suction). However, the highest ATPase activity and starch conversion rate was observed in respiratory organs in A horizon of Madampe series. Moreover, the starch and proline accumulation in different parts of coconut seedling positively related with soil physical and water stress conditions (100-1500 kPa) prevalence in ' $A$ ' and ' $B$ ' horizons of Madampe and Andigama series respectively.
\end{abstract}

Keywords: ATPase activity, Glucose, Proline, Soil physical characters, Starch, Water stress

\section{INTRODUCTION}

Coconut (Cocos nucifera L.) is one of the major plantation crops in Sri Lanka, which covers about 416,000 ha being found on different soil types with divers moisture regimes. Amongst soil constraints, soil physical limitations including water deficiency of soils are known to be key factors adversely affecting the physiological and morphological adaptation of coconut roots (Vidhana Arachchi, 2000).

Nutrition, water and aeration aspects of soils are governed mainly by soil physical properties (Arkin and Taylor, 1981). Root system functions, such as storage, synthesis of growth regulators, propagation and dispersal are linked with availability of air, water and nutrient in the root-soil-interface (Yoav and Amram, 1991). In fact, nutrient acquisition by plants can be understood only if allowance is made for the properties of the soil as the natural environment of roots. However, the major processes and factors that contribute to and interact in the transfer of nutrients from soil to plants are not well documented (Albrecht, 1991). \footnotetext{
${ }^{1}$ Department of Export Agriculture, Faculty of Agricultural Sciences, Sabaragamuwa University 108
of Sri Lanka

${ }^{2}$ Coconut Research Institute, Lunuwila, Sri Lanka

${ }^{3}$ Department of Livestock Production, Faculty of Agricultural Sciences, Sabaragamuwa

University of Sri Lanka
} 
As far as coconut is concerned, nutrient and water are absorbed through absorption cells (Child, 1974) and gasses exchange mainly through respiratory organs of coconut (Davis, 1968; Vidhana Arachchi, 2000). Hence different stress conditions, specially water and physical stress in the root soil interface could hinder the nutrient, water and air absorption processes which in turn would result in interference of biochemical and physiological process of plants (Barber, 1984). Therefore, studies on the effect of soil physical and water stress on biochemical functions of coconut seedlings are useful to identify the major constraints related to coconut production.

Major bio-chemical reactions such as ATPase activity, carbohydrate-glucose conversion, proline accumulation and their inter relationships are linked with absorption and respiratory process of plants (Gluthe, 1968). An important feature of the respiration in higher plants, particularly in roots, is the participation of an alternative, nonphosphorylating electron transport pathway, which reduces the efficiency of ATP production in respiration (Lambers, 1985). The contribution of this path way to root respiration depends strongly on the species under investigation and on environmental conditions and respiratory energy is the driving force for biosynthetic reactions and transport process (Lambers et al., 1991).

Most of the biological energy required for growth and development of crops through respiratory path ways involving oxidation of sugar. The sugar supply of tissues varies depending upon factors which affect the efficiency of carbon fixation by leaves and transport of the recently synthesized carbohydrates (Pierre and Alain, 1980). For conversion of carbohydrate to simple sugars and their translocation and accumulation in different parts of plant respiratory energy, is required.

Severe water stress and physical stress are known to induce numerous metabolic irregu- larities in plants (Bates, 1973; Verbruggen and Hermans, 2008). Accumulation of free proline under stress conditions is one such irregularity reported by many workers in many higher plants. Bates (1973) reported that proline is more sensitive for water stress compared to other amino acids. Proline accumulation in plant tissues depend on, variety and age of plant, kind of stress and intensity of stress (William and Sharon, 1981; Roberto et al; 2009). Therefore, proline accumulation in plant tissues is appropriate indicator to evaluate the soil physical and moisture stress of different conditions of soils.

ATPase activity in root cells, carbohydrate and simple sugar conversion and proline accumulation in plant tissues are changed according to the intensity and kind of stress. Hence, study of their inter-relationship in respect to soil physical and moisture stress will be extremely useful to identify the major physical constrains that are significantly affecting the growth performance of coconut palm. Furthermore, studies of kinetic parameters under different soil and water stress condition in relation to growth of coconut seedlings are not documented.

Therefore, objective of this study was to examine the accumulation of proline, ATPase activity in root cells, starch conversion to glucose in leaf tissues of coconut seedlings and their interrelationships with respect to soil physical and water stress.

\section{MATERIALS AND METHODS}

\section{Experimental sites}

Field experiments were conducted for two soil series namely, Andigama and Madampe series. The field experiment conducted in Andigama series was located at Rathmalagama estate, Madampe in the Low Country (08002N, 790E; 35m altitude), Intermediate climate zone (the annual rainfall and ambient temperature were $1660 \mathrm{~mm}$ and 23.8-30.4 ${ }^{\circ} \mathrm{C}$ ) of Sri Lanka. Madampe series (light-textured 
high productive soil) was located in Bandirippuwa estate, Lunuwila in the Low Country Intermediate climate zone $(08002 \mathrm{~N}, 790 \mathrm{E}$, $35 \mathrm{~m}$ altitude). Andigama and Madampe soil series belong to the great soil groups Red Yellow Podsolic (Rhodudults/Tropudults; USDA classification) and Latosols and Resosols on old Red and yellow sands ( Quartzipsamnents; USDA classification), respectively.

The experiment was established with selected homogenous coconut seedlings which were placed in different horizons of Madampe and Andigama series. Soil horizons of both series have identified as described by Somasiri et.al. (1994). Each horizon was then exposed to place coconut seedlings. It was a completely randomized design with six replicates, with each having five coconut seedlings.

Polythene sealed cement circles $(50 \mathrm{~cm}$ in diameter $\mathrm{x} 10 \mathrm{~cm}$ in height) were placed around each coconut seedlings in order to manage the moisture level near root zone of coconut seedling properly. Polythene was used to minimize any effect of cement that may have on soil environment around coconut seedling.

After one and half years of the establishment of 6 month old coconut seedlings in different horizons of both series, the moisture contents at three depletion levels viz. 10-30 kPa, 10 $100 \mathrm{kPa}$ and $10-1500 \mathrm{kPa}$ were maintained in order to create moisture stress around roots of coconut seedlings, during the dry period. Moisture characteristics curve and calibrated neutron probe were used to find out the time period required for water depletion from field capacity to above particular moisture levels and the field capacity of soil was maintained using tensiometers. The experiment was conducted for four months in the dry period.

\section{Soil physical properties}

Physical properties of soils from major soil series used for coconut production in Sri Lanka were measured (Table 01) using 10 randomly selected centers of coconut squares. Soil sam- ples were taken from each soil horizon of both series to determine the texture, bulk density, Penetrometer resistance and soil water status. Undisturbed soil samples were taken for bulk density, aeration and moisture determination using steel core samplers, the dimension of which are $7.5 \mathrm{~cm}$ in diameter and $5 \mathrm{~cm}$ height for bulk density and $4.5 \mathrm{~cm}$ in diameter and $3.5 \mathrm{~cm}$ in height for soil moisture determination. Soils in the core sampler for moisture determination were transferred to aluminum rings $(4.5 \times 3 \mathrm{~cm})$ for water retention measurements. The core samples were wrapped in polythene to prevent drying and transported to the laboratory. Undisturbed samples were saturated and water retention measurements were taken using standard pressure plate apparatus as described by Klute (1986) for determination of total available water. The gravimetric water content at each suction level was estimated and converted to the volumetric water content using the corresponding bulk densities. Total porosity was used as the volumetric water content at saturation corresponding to zero suction level. Pores which were unable to hold water at $10 \mathrm{kPa}$ (Diameter $0.03 \mathrm{~mm}$ ) were designated as macro pores and the rest as micro pores.

The degree of soil compaction, which is an indication of resistance to root penetration, was examined using a cone penetrometer (Penetrograph STIBOKA, The Netherlands) as described by Bradford (1986). A uniform pressure was applied to the hand grips of cone penetrometer and the cone $(2 \mathrm{~cm}$, diameter) was pushed vertically into the ground two each horizon at a constant rate of $2 \mathrm{~cm} / \mathrm{s}$. Penetrometer readings were taken at surface of each horizon of both soil profiles. Measurements were taken in the dry period to minimize the error that may occur due to the different antecedent soil moisture levels. 
Table 01: Physical properties of different horizons of Andigama and Madampe soil series

\begin{tabular}{|c|c|c|c|c|c|c|}
\hline \multirow{2}{*}{$\begin{array}{c}\text { Parameter } \\
\text { Horizons }\end{array}$} & \multicolumn{3}{|c|}{ Andigama series } & \multicolumn{3}{|c|}{ Madampe series } \\
\hline & $\mathbf{A}$ & $\mathbf{A B}$ & B & $\mathbf{A}$ & $\mathbf{A B}$ & B \\
\hline $\mathrm{FC}(\%)$ at $10 \mathrm{kpa}$ & $15.86 \pm 2.6$ & $15.65 \pm 2.7$ & $17.09 \pm 4.0$ & $9.87 \pm 1.83$ & $10.41 \pm 2.70$ & $10.97 \pm 1.72$ \\
\hline PWP (\%) at1500kpa & $6.81 \pm 2.5$ & $9.29 \pm 1.9$ & $13.6 \pm 3.54$ & $4.15 \pm 1.11$ & $3.73 \pm 1.08$ & $4.28 \pm 1.20$ \\
\hline TAW (\%) & 9.05 & 6.38 & 3.54 & 5.71 & 6.18 & 6.7 \\
\hline RAW (\%) 10-100kpa & 6.46 & 4.55 & 2.20 & 3.96 & 5.30 & 5.68 \\
\hline $\mathrm{BD}\left(\mathrm{g} / \mathrm{cm}^{3}\right)$ & $1.45 \pm 0.12$ & $1.55 \pm 0.3$ & $1.6 \pm 0.12$ & $1.35 \pm 0.1$ & $1.4 \pm 0.2$ & $1.45 \pm 0.3$ \\
\hline Macro pores $(\%)$ & $28 \pm 5.0$ & $26 \pm 6.0$ & $15 \pm 3.0$ & $8 \pm 6.0$ & $36 \pm 7.0$ & $34 \pm 4.0$ \\
\hline $\begin{array}{l}\text { Penetrometer resis- } \\
\text { tance }\left(\mathrm{N} / \mathrm{cm}^{2}\right)\end{array}$ & $250 \pm 25$ & $310 \pm 30$ & $450 \pm 60$ & $210 \pm 30$ & $260 \pm 40$ & $280 \pm 35$ \\
\hline Micro pores $(\%)$ & $10 \pm 2.0$ & $9.0 \pm 1.5$ & $9.5 \pm 1.5$ & $15 \pm 3.0$ & $16 \pm 1.5$ & $17 \pm 2.0$ \\
\hline Sand $(\%)$ & $65 \pm 5.0$ & $60 \pm 8.0$ & $55 \pm 10$ & $83 \pm 11$ & $81 \pm 14$ & $75 \pm 10$ \\
\hline Silt $(\%)$ & $10 \pm 2.0$ & $11 \pm 1.0$ & $12 \pm 2.0$ & $5.0 \pm 0.5$ & $4 \pm 0.6$ & $4.5 \pm 0.5$ \\
\hline Clay (\%) & $20 \pm 5.0$ & $23 \pm 6.0$ & $30 \pm 8.0$ & $10 \pm 2.0$ & $12 \pm 3.0$ & $14 \pm 1.2$ \\
\hline
\end{tabular}

FC- Field Capacity, PWP- Permanent Wilting Point, TAW- Total Available Water, RAW- Readily Available Water, BD- Bulk Density.

\section{Soil water depletion}

Soil moisture measurements in every treatment were taken using neutron moisture meter (Troxler, Model 4302 and Serial No. 166). Aluminum access tubes were installed in every treatment using a steel guide tube up to a depth of $1 \mathrm{~m}$, leaving $20 \mathrm{~mm}$ exposed above ground level. The tubes were then sealed with rubber bungs. The neutron probe was calibrated with respect to each soil horizon of $\mathrm{An}$ digama and Madampe soil series.

The soil moisture was measured during the period in each soil profile near the coconut seedlings and each horizon of, bare soil (control) of both Andigama and Madampe series. Total soil moisture fluctuation in every treatment during the experimental period was calculated as suggested by Bell (1987).

\section{ATPase assay}

For the determination of ATPase activity, the plasmamembrane rich microsomal fraction of the roots and leaves was used. Roots, leaves and respiratory organs of coconut were excised separately and washed with demineralized water three times, and the fresh weight of each part was determined. Five grams of roots, leaves and $0.5 \mathrm{~g}$ of respiratory organs were cut into small pieces and homogenized for $3 \mathrm{~min}$ in $50 \mathrm{ml}$ buffer solution $(0.25 \mathrm{M}$ sucrose, 1 $\mathrm{mM}$ EDTA, $10 \mathrm{mM}$ Tris-HCl, $\mathrm{pH}$ 7.0). The homogenate was filtered through four layers of cheese cloth. The filtrate was differentially centrifuged in a Sorvallcentrifuge for $10 \mathrm{~min}$ at $2000 \mathrm{~g}$, then the supernatant for $10 \mathrm{~min}$ at $10,000 \mathrm{~g}$, and finally the microsomal fraction was spun down at $30,000 \mathrm{~g}$ for $60 \mathrm{~min}$. The pellet was re-suspended in ten $\mathrm{ml}$ of buffer solu- 
tion and homogenized with a potter-Elvehjem glass homogenizer. Temperature was continuously kept at $0{ }^{\circ} \mathrm{C}-4{ }^{\circ} \mathrm{C}$. Samples were stored in a deep freezer at $-20{ }^{\circ} \mathrm{C}$ in small portions in order to expose the enzyme preparation to a single freeze-thaw cycle for each experiment.

ATPase activity was determined at $25{ }^{\circ} \mathrm{C}$ in $1 \mathrm{ml}$ volume, containing $1 \mathrm{mM} \mathrm{ATP,} 10$ $\mathrm{mM}$ histidine $-\mathrm{HCl}$ buffer ( $\mathrm{pH}$ 6.7), $3.0 \mathrm{mM}$ $\mathrm{MgSO}_{4}$ and $50 \mathrm{mM} \mathrm{KCl}$ solution. The reaction was stopped after 30 min by adding 0.1 $\mathrm{ml} 33 \%$ TCA (Trichloro acetic acid) and the reaction vessels were placed in ice. Four $\mathrm{ml}$ of ice cold water was added to each tube in order to dilute the protein precipitated by TCA. Inorganic phosphate was determined by the ammonium molybdate $-\mathrm{SnCl}_{2}$ method of lindeman (1958). ATPase activity was calculated on a fresh weight basis. For determination of the protein content, proteins were precipitated with TCA, spun down by centrifugation, the pellet dissolved again in $0.1 \mathrm{M} \mathrm{NaOH}$. The protein content was determined by the method of Lowry et al., (1951). Same procedure was followed for every sample for determination of ATPase activity in different soil physical and moisture stress in situ condition.

\section{Starch and glucose determination}

Fresh, finely cut plant materials were heated, immediately after harvesting, in water at 100 ${ }^{0} \mathrm{C}$ for $5 \mathrm{~min}$ to deactivate enzymes. Samples were then dried at $60{ }^{\circ} \mathrm{C}$ for two days and ground and sieved using $0.5 \mathrm{~mm}$ sieve. The respiratory organs were ground using porcelain pestle. Carbohydrate and glucose contents were then determined following the method of Dubois et al., (1956).

\section{Extraction procedure}

Ten $\mathrm{ml}$ of $80 \%$ ethyl alcohol was added into $0.5 \mathrm{~g}$ of dried sample and kept in a water bath at $60{ }^{\circ} \mathrm{C}$ for 15 minutes. Supernatant layer was separated by centrifugation at $3500 \mathrm{rpm}$ for 5 min. Added another $7.0 \mathrm{ml}(5.0 \mathrm{ml}+2.0 \mathrm{ml})$ of $80 \%$ ethyl alcohol to the residue and kept in a water bath at $60{ }^{\circ} \mathrm{C}$ for $15 \mathrm{~min}$. It was centrifuged again to obtain supernatant layer. Added $5.0 \mathrm{ml}$ of $\mathrm{CHCl}_{3}$ \& $10.0 \mathrm{ml}$ of distilled water to liquid portion and allowed it to settle after shaking well. Removed the $\mathrm{CHCl}_{3}$ layer containing chlorophyll and the final volume of liquid portion made up to $5 \mathrm{ml}$.

\section{Analysis of total soluble sugars}

Added $0.98 \mathrm{ml}$ of distilled water to $10 \mu \mathrm{l}$ of the sample and mixed well with $5 \%$ phenol solution. Using a pipette with a slightly broken tip pored $5.0 \mathrm{ml}$ of con. $\mathrm{H}_{2} \mathrm{SO}_{4}$ into the solution rapidly and was shaked well. The intensity of color was then measured using a spectrophotometer at $490 \mathrm{~nm}$.

\section{Preparation of the residue for starch analy- sis}

Added $10.0 \mathrm{ml}$ of distilled water to the residue and boiled it for $15 \mathrm{~min}$. Mixed the solution with $1 \%$ amylase (prepared in $0.2 \mathrm{M}$ sodium acetate buffer with $4.45 \mathrm{pH}$ value) and mixed well. Covered the test tube by parafilm and kept the tube with solution in a water bath at $42^{\circ} \mathrm{C}$ overnight for conversion of starch into simple sugar. After completion of above procedure the sample was centrifuged at 3500 rpm for $5 \mathrm{~min}$ and separated the liquid portion for the determination of converted simple sugars using the procedure described above. Purified glucose was used to standardize the procedure for quantifying sample value.

\section{Proline determination}

In leaves, sampling was done for the fourth leaf, in roots, in the root absorption zone and the respiratory organs of field-grown coconut seedlings. The method used for proline determination as described by Bates (1973). Purified proline was used to standardize the procedure for quantifying sample values.

Acid-ninhydrin was prepared by warming 1.25 g ninhydrin in $30 \mathrm{ml}$ glacial acetic acid and 20 $\mathrm{ml} 6 \mathrm{M}$ phosphoric acid, until dissolved. Kept cool (stored at $4^{\circ} \mathrm{C}$ ) the reagent remains stable 24 hours. Then approximately $0.5 \mathrm{~g}$ of plant 
materials was homogenized in $10 \mathrm{ml}$ of $3 \%$ sulfosalicylic acid and the homogenate filtered through Watman \# 2 filter paper. Two ml of filtrate was reacted with $2 \mathrm{ml}$ acid-nihydrin and $2 \mathrm{ml}$ of glacial acetic in a test tube for $1 \mathrm{~h}$ at 10 ${ }^{0} \mathrm{C}$, and the reaction terminated in an ice bath. The reaction mixture was extracted with $4 \mathrm{ml}$ toluene, mixed vigorously with a test tube stirrer for 15-20 sec. The chromophore containing toluene was aspirated from the aqueous phase, warmed to room temperature and the absorbance read at $520 \mathrm{~nm}$ using toluene for blank. The proline concentration was determined from a standard curve and calculated on a fresh basis (Bates, 1973).

\section{Data analysis}

A completely randomized design with six replicates for treatments was used and all data were analyzed using JMP Statistical Discovery Software Package (Version 3.2.2) produced by SAS Institute. Analysis of variance and the mean comparison of treatments were performed using Tukey-Kramer Honestly Significant Difference (HSD) test at different probability levels $(\mathrm{P}<0.05, \mathrm{P}<0.01$, and $\mathrm{P}<$ 0.001).

\section{RESULTS AND DISCUSSION}

Soil physical parameters of different horizons of Andigama and Madampe soil series are indicated in Table 01 . Total and readily available water fraction restricted in B horizon of Andigama series due to high soil compaction (BD $>1.6$ and penetrometer resistant $>450$ $\mathrm{N} / \mathrm{cm}^{3}$ ). Readily available water is extremely useful for crop production. Specially, roots can uptake water retained at 1 bar level $(100 \mathrm{kPa})$ without wasting more energy (Vidhana Arachchi, 2009). The both available water fractions were higher in 'A' horizon of Andigama series and $\mathrm{AB}$ and $\mathrm{B}$ horizons of Madampe series due to prevailing optimum clay content under low compaction. Total porosity ( Micro + Macro pores volume) was greater in 'A' horizon of Andigama and Madampe series could be due to prevalence of their sandy nature resulted in high aeration capacity in ' $A$ ' horizon of both series.

In accordance with changes in bulk density, penetrometer resistance increased, while total air-filled porosity decreased significantly $(\mathrm{P}<$ $0.05)$ due to sub soil compaction specially in $\mathrm{AB}$ and $\mathrm{B}$ horizon of Andigama series. When soil bulk density increased from 1.12 to $1.62 \mathrm{~g}$ $/ \mathrm{cm}^{3}$ root growth of L.glutinosa was severely affected (Liang et.al., 1999). Soil compaction often alters soil properties, resulting changes in plant available water. Results also clearly showed that total and readily available water fraction and micro pores volumes increased significantly $(\mathrm{P}<0.05)$ with clay content of soil.

Overall soil physical properties explained that high clay content under compaction limited aeration and water status of different horizons of Andigama and Madampe soil series.

\section{Preliminary study}

A preliminary study was conducted to examine the degree of response of different parts of coconut seedlings on ATPase, starch, glucose and proline accumulation. Results revealed that third leaf of coconut seedling has much potential to response to starch and glucose contents, proline accumulation and ATPase activity compared to other leaves of coconut seedling.

The results also showed that absorption zones of primary, fine roots and respiratory organs had a higher concentration of starch, proline and also higher ATPase activity compared to lignified roots. Hence third leaf, absorption zones of primary and fine roots together and respiratory organs were taken to study the biochemical parameters with respect to soil physical and moisture stress under field condition. 
ATPase activity in leaves, absorption cells and respiratory organs of coconut seedling

\section{ATPase activity}

Determination of ATPase was based on ability of plant tissues to release Pi. ATPase activity of leaves, absorption cells and respiratory organs of coconut seedling grown in different horizons of Andigama and Madampe series under different moisture depletion levels is shown in Table 02. Hideaki et al., (1993) reported that ATPase activity of plasma membrane is a good marker enzyme in studies on the changes of the plasma membrane associated with various environmental stresses. The V-ATPase is the dominant $\mathrm{H}^{+}$- pump at endomembranes of most plant cells, both in terms of protein amount and frequently, also in activity (Dietz et.al. 2001). He also reported that under stress conditions such as salinity, drought, cold, acid stress, low oxygen and excess heavy metal in the soil, survival of the cells depends strongly on maintaining or adjusting the activity of the V-ATPase.

\section{ATPase activity in leaves}

Results indicated that ATPase activity in leaves of coconut seedlings in $\mathrm{A}, \mathrm{AB}$ and $\mathrm{B}$ horizons of Andigama series do not show any significant differences as a result of moisture stress, but ATPase activity was higher in A and AB horizons compared to B horizon. The lowest ATPase activity was observed in B horizon at higher moisture stress level $(100 \mathrm{kPa}$ to $1500 \mathrm{kPa}$ section). The ion absorption by coconut roots in $\mathrm{B}$ horizon could therefore be low compared to $\mathrm{A}$ and $\mathrm{AB}$ horizons (Table 02). Marianne (1985) reported that plasmalemma ATPase activity play an important role on ion absorption through plasmalemma and that can be restricted by the condition of soil environment in the root-soil interface.

The ATPase activity in leaves of coconut seedlings grown in Madampe series showed a significant difference $(\mathrm{P}<0.001)$ with respect to horizons and moisture stress conditions. ATPase activity increased with depth and de- creased with moisture stress (Table 03). The highest ATPase activity was observed in the $\mathrm{B}$ horizon of Madampe series in respect to the moisture level at field capacity $(10 \mathrm{kPa}$ to 30 $\mathrm{kPa}$ suction), while the lowest activity was observed in the A horizon at high water stress condition (100 $\mathrm{kPa}$ to $1500 \mathrm{kPa}$ suction). It appears that mineral nutrient absorption by coconut roots in $\mathrm{AB}$ and $\mathrm{B}$ horizons could be higher compared to A horizon of Madampe series. Fisher et al., (1970) reported that ATP is the energy source for ion transport in roots and that an ATPase participated in the energy transduction process involved in energy dependent ion transport. High sandy nature of 'A' horizon of Madampe series would not be favor to ATPase activity.

\section{ATPase activity in absorption cells}

ATPase activity in absorption cells of coconut seedlings grown in Andigama and Madampe series showed a significant difference $(\mathrm{P}<$ 0.05 and $\mathrm{P}<0.001$ respectively) with respect to depth and moisture levels (Table 02 and 03). The effect of soil horizons and moisture levels on ATPase activity of absoption cells showed similar results to that of leaves. Poor physical characteristic of B horizon of Andigama and A horizon of Madampe series could be responsible for low ATPase activity of absorption cells. This may be one of the reasons for the growth retardation of coconut seedlings grown in A and B horizons of Madampe and Andigama series respectively. 
Table 02: ATPase activity of leaves, root absorption cells and respiratory organs of coconut seedlings under different soil physical and moisture stress in Andigama series.

\begin{tabular}{llcl}
\hline $\begin{array}{l}\text { Treatments depth and } \\
\text { moisture levels }\end{array}$ & \multicolumn{3}{c}{$\begin{array}{c}\text { ATPase activity } \\
\text { Pi }(\boldsymbol{\mu} \text { mol/mg protein, h) } \\
\text { Absorption cells }\end{array}$} \\
\hline AM1 & Respiratory organs \\
\hline ABM1 & $3.32 \pm 2.00$ & $4.71 \pm 1.80$ & $3.50 \pm 0.70$ \\
BM1 & $3.45 \pm 0.74$ & $3.20 \pm 0.80$ & $2.90 \pm 0.60$ \\
AM2 & $1.75 \pm 0.64$ & $2.38 \pm 1.10$ & $2.81 \pm 1.10$ \\
ABM2 & $2.80 \pm 0.28$ & $4.20 \pm 0.30$ & $2.73 \pm 0.40$ \\
BM2 & $2.28 \pm 0.28$ & $3.52 \pm 0.60$ & $2.10 \pm 0.43$ \\
AM3 & $1.80 \pm 0.65$ & $1.81 \pm 0.96$ & $2.30 \pm 1.10$ \\
ABM3 & $1.84 \pm 0.30$ & $2.34 \pm 0.70$ & $2.96 \pm 2.10$ \\
BM3 & $2.93 \pm 2.40$ & $2.85 \pm 2.20$ & $2.60 \pm 0.50$ \\
Significance & $1.77 \pm 1.30$ & $1.15 \pm 0.60$ & $0.63 \pm 0.21$ \\
CV \% & NS & $*$ & $*$ \\
LSD & 51.74 & 29.20 & 28.3 \\
\hline
\end{tabular}

A, AB and B soil horizons.M1: $10 \mathrm{kPa}-30 \mathrm{kPa}$; 2 : $10 \mathrm{kPa}-100 \mathrm{kPa}$; M3:10 kPa -1500 kPa depletion levels; CV\%- covariant; LSD-least significant different; ${ }^{*}$-p $<0.05$.

Table 03: ATPase activity of leaves, root absorption cells and respiratory organs of coconut seedlings under different soil physical and moisture stress in Madampe series

\begin{tabular}{llll}
\hline $\begin{array}{l}\text { Treatments depth and } \\
\text { moisture levels }\end{array}$ & \multicolumn{3}{c}{$\begin{array}{c}\text { ATPase activity } \\
\text { Pi }(\boldsymbol{\mu} \text { mol/mg protein, } \mathbf{h}) \\
\text { Absorption cells }\end{array}$} \\
AM1 & $3.50 \pm 0.50$ & $5.70 \pm 0.40$ & \multicolumn{1}{c}{ Respiratory organs } \\
ABM1 & $6.20 \pm 0.60$ & $5.84 \pm 1.50$ & $24.1 \pm 10.0$ \\
BM1 & $6.90 \pm 0.50$ & $7.97 \pm 0.70$ & $13.0 \pm 5.60$ \\
AM2 & $2.50 \pm 0.30$ & $2.20 \pm 0.30$ & $6.20 \pm 1.20$ \\
ABM2 & $4.10 \pm 0.04$ & $2.41 \pm 1.11$ & $4.80 \pm 1.30$ \\
BM2 & $2.60 \pm 0.80$ & $1.90 \pm 0.30$ & $3.20 \pm 0.40$ \\
AM3 & $2.50 \pm 0.80$ & $1.30 \pm 0.40$ & $3.60 \pm 0.70$ \\
ABM3 & $2.90 \pm 1.00$ & $1.50 \pm 0.20$ & $2.50 \pm 1.20$ \\
BM3 & $2.60 \pm 0.80$ & $1.90 \pm 0.30$ & $3.20 \pm 0.40$ \\
Significance & $* * *$ & $* * *$ & $* * *$ \\
CV \% & 18.98 & 23.81 & 28.43 \\
LSD & 1.276 & 1.432 & 6.770 \\
\hline
\end{tabular}

A, AB and B soil horizons. M1: $10 \mathrm{kPa}-30 \mathrm{kPa} ; \mathrm{M} 2$ : $10 \mathrm{kPa}-100 \mathrm{kPa}$; M3:10 kPa -1500 kPa depletion levels; CV $\%$ - covariant; LSD-least significant different; ${ }^{* * *}$-P $<0.001$. 


\section{ATPase activity in respiratory organs}

Pairwise LSD test also showed that ATPase activity of respiratory organs in Madampe and Andigama series had differed significantly ( $\mathrm{P}$ $<0.001$ and $\mathrm{P}<0.05$ respectively) with respect to depth and moisture levels (Table 02 and 03). Results also emphasized that ATPase activity is very sensitive to moisture stress compared to soil physical stress. ATPase activity decreased sharply in Madampe series with moisture stress. Bert et al., (1981) reported that ATPase activity in oat roots was higher in low salt concentration than higher salt concentration. Soil physical and moisture stress have led to a reduction of ATPase activity of respiratory organs of coconut seedlings.

The ATPase activity of respiratory organs of coconut seedlings grown in A horizon of Madampe series was higher compared to its $\mathrm{AB}$ and $\mathrm{B}$ horizon. This could be due to favorable conditions such as high aeration due to high macro pores of sandy nature provided by the A horizon of Madampe series. It has been shown that A horizon of Madampe series provides good aeration for respiratory activities and this could have resulted in higher number of respiratory organs in A horizon of Madampe series compared to other horizons. Witold and Arazyna (1992) reported that respiratory activity of roots depends on some external factors such as oxygen, temperature, carbon dioxide, soil mechanical impedance and also on some internal factors specific for a given plant, connected with its genetic background, physiological age, metabolic reaction rate etc. William (1948) and Raymond and Pradet (1980) have shown that limitation of respiratory metabolism by low $\mathrm{O}_{2}$ partial pressure induces a drop of energy charge which stabilizes at values apparently well correlated with the actual level of cellular metabolic activity. Hendrik et al., (1991) reported that the rate of root respiration was positively correlated with the relative growth rate of plant roots. $\mathrm{He}$ also reported that fast growing stages of crops had higher ATPase activity which linked with respiratory energy and lead to increased nutrient uptake rate compared to lower growth rate period of crops. According to Witold and Arazyne (1992) the uptake of macro elements decreased at low oxygen availability. Oxygen diffusion rates of $>30 \mathrm{ug} \mathrm{m}^{-2} \mathrm{~m}^{-1}$ were needed for adequate nutrient uptake of winter rye.

\section{Starch content in leaves}

Starch concentration in leaves of coconut seedling in Andigama series was found to decrease with increasing depth of soil profile, on the contrary, an increase in starch level with increasing depth of soil profile was observed in Madampe series (Table 05). In addition, LSD test showed that no significant variation in starch concentration of leaves due to treatments was observed in both series. However, starch concentration in leaves of coconut seedling in Madampe series was higher that of leaves of coconut seedling grown in Andiga$m a$ series. Further, the highest and the lowest starch concentrations were observed in the B horizons of Madampe and Andigama series respectively.

\section{Starch content in absorption cells}

It was observed that starch concentration in absorption cells of coconut seedlings increased in A and B horizons of Madampe series with respect to moisture stress whilist the soil conditions of $\mathrm{AB}$ and $\mathrm{B}$ horizons of Andigama series were found to adversely affect the starch content of absorption cells. The starch content increased with respect to depth in Madampe series when available water in the profile was higher (at field capacity level). Pairewise comparison with LSD test showed that the starch concentration of absorption cells of Andigama series was significantly $(\mathrm{P}<0.01)$ lower than that of Madampe series. 
Table 04: Starch concentration of leaves, root absorption cells and respiratory organs of coconut seedlings under different soil physical and moisture stress in Andigama series

\begin{tabular}{llcl}
\hline $\begin{array}{l}\text { Treatments depth and } \\
\text { moisture levels }\end{array}$ & \multicolumn{3}{c}{$\begin{array}{c}\text { Starch concentration } \\
\text { \% } \\
\text { Leaves }\end{array}$} \\
AM1 & $4.90 \pm 1.70$ & $4.00 \pm 0.70$ & $3.70 \pm 1.10$ \\
ABM1 & $4.10 \pm 0.30$ & $4.30 \pm 0.20$ & $2.50 \pm 0.70$ \\
BM1 & $3.60 \pm 1.20$ & $4.10 \pm 0.30$ & $2.50 \pm 1.20$ \\
AM2 & $5.40 \pm 0.40$ & $4.00 \pm 1.00$ & $1.50 \pm 0.30$ \\
ABM2 & $5.50 \pm 1.60$ & $3.30 \pm 0.70$ & $1.40 \pm 0.30$ \\
BM2 & $3.10 \pm 1.10$ & $2.70 \pm 0.50$ & $1.40 \pm 0.40$ \\
AM3 & $4.20 \pm 0.90$ & $3.80 \pm 0.80$ & $1.70 \pm 0.70$ \\
ABM3 & $3.60 \pm 0.70$ & $3.20 \pm 0.90$ & $2.00 \pm 1.00$ \\
BM3 & $2.90 \pm 1.10$ & $2.00 \pm 0.90$ & $2.10 \pm 1.60$ \\
Significance & NS & $*$ & $*$ \\
CV \% & 28.50 & 21.59 & 43.20 \\
LSD & - & 1.290 & 1.540 \\
\hline
\end{tabular}

$\mathrm{A}, \mathrm{AB}$ and $\mathrm{B}$ soil horizons. $\mathrm{M} 1: 10 \mathrm{kPa}-30 \mathrm{kPa}$; $2: 10 \mathrm{kPa}-100 \mathrm{kPa}$; $33: 10 \mathrm{kPa}-1500 \mathrm{kPa}$ depletion levels; CV\%- covariant; LSD-least significant different; ${ }^{*}$-p $<0.05$.

\section{Starch content in respiratory organs}

The starch content of respiratory organs in A horizon of Madampe series was found to be higher than that of $\mathrm{AB}$ and $\mathrm{B}$ horizons and it decrease with the depth of soil profile except in the treatment of moisture level $10 \mathrm{kPa}$ to $100 \mathrm{kPa}$ (Table 05). In Andigama series, starch level decreased with the depth of soil profile. The depth of both soil profiles was found to strongly affect the function of respiratory organs of coconut seedlings. In Andigama series, the moisture level at field capacity (10 $\mathrm{kPa}$ to $30 \mathrm{kPa}$ ) promoted the function of respiratory organs (Table 04). High starch accumulation was observed in the respiratory organs in $\mathrm{A}$ and $\mathrm{AB}$ horizons of Madampe series compared to B horizon. Pairwise LSD test showed that the starch concentration in the respiratory organs in Madampe and Andigama series significantly changed with respect to the depth and moisture levels. Those significant values were $\mathrm{P}<0.001$ and $\mathrm{P}<0.05$ respectively. In addition, moisture reduction in $\mathrm{A}$ and $\mathrm{AB}$ horizons of Madampe series and $\mathrm{B}$ horizon of Andigama series (1 kPa to $1500 \mathrm{kPa}$ moisture level) increased the starch level of respiratory organs.

\section{Glucose content in leaves}

Glucose concentration in leaves of coconut seedlings was significantly low in Andigama series $(\mathrm{P}<0.001)$ and high in Madampe series $(\mathrm{P}<0.01)$ with respect to the depth and moisture levels (Table 06 and 07). Glucose concentration of leaves of both series was considerably high at moisture level at field capacity $(10 \mathrm{kPa}$ to $30 \mathrm{kPa})$. Moisture level had a more profound effect than the depth of soil profiles on glucose content (Table 06 and 07). Martine et. al., (1992) reported that recovery of enzyme activities is only marginally better in starved roots compared with non-starved 
roots, indicating an increase in beta oxidation activity during starvation. This increase is probably an essential part of the response to a situation in which lipids and protein replace carbohydrate as the major respiratory substrate. Soluble sugars are highly sensitive to environmental stress, which act on the supply of carbohydrates from source organ to sink (Rosa et. al., 2009)

\section{Glucose content in absorption cells}

The absorption cells were found to have a higher glucose content compared to other parts of coconut seedlings indicating a higher biochemical and physiological activity in absorption cells. Vidhana Arachchi et. al., (2000) reported that absorption cells play a major role in absorption of nutrients and water. Glucose concentration in absorption cells of both series were significantly $(\mathrm{P}<0.001)$ higher with respect to moisture level of soil profile, while it was the highest at the field capacity $(10 \mathrm{kPa}$ to $30 \mathrm{kPa}$ ) level. Results clearly showed that the higher moisture levels had a more profound effect in increasing the glucose concentration than the soil physical stress in Glucose and Sucrose accumulation was inhibited in maize roots under soil stress condition (Atsushi et. al., 2005) depth of soil profiles.

Soluble sugars are highly sensitive to environmental stresses, which act on the supply of carbohydrates from source organs to sink ones (Ali- Ahmad and Basha, 1998). Growth and development of lateral roots of maize was greatly promoted with accumulation of glucose in plant tissues under water stress condition (Atsushi et. al., 2005).

Table 05: Starch concentration of leaves, root absorption cells and respiratory organs of coconut seedlings under different soil physical and moisture stress in Madampe series

\begin{tabular}{llll}
\hline $\begin{array}{l}\text { Treatments depth and } \\
\text { moisture levels }\end{array}$ & Leaves & $\begin{array}{c}\text { Starch concentration } \\
\text { \% } \\
\text { Absorption cells }\end{array}$ & Respiratory organs \\
\hline AM1 & $5.20 \pm 0.10$ & $8.40 \pm 3.60$ & $9.30 \pm 3.90$ \\
ABM1 & $5.10 \pm 0.30$ & $9.00 \pm 3.70$ & $2.96 \pm 0.70$ \\
BM1 & $7.40 \pm 2.60$ & $9.58 \pm 4.60$ & $1.20 \pm 0.70$ \\
AM2 & $5.10 \pm 1.20$ & $6.80 \pm 3.90$ & $4.70 \pm 1.50$ \\
ABM2 & $6.70 \pm 2.40$ & $7.10 \pm 1.10$ & $5.70 \pm 3.30$ \\
BM2 & $6.80 \pm 0.80$ & $6.70 \pm 2.50$ & $4.10 \pm 1.40$ \\
AM3 & $4.20 \pm 0.10$ & $9.70 \pm 1.60$ & $7.10 \pm 2.20$ \\
ABM3 & $5.95 \pm 3.20$ & $9.50 \pm 0.60$ & $5.90 \pm 2.70$ \\
BM3 & $6.20 \pm 1.60$ & $8.20 \pm 3.90$ & $2.10 \pm 0.97$ \\
Significance & $* * *$ & $* * *$ & $* * *$ \\
CV \% & 18.98 & 23.81 & 48.43 \\
LSD & 1.276 & 1.432 & 6.77 \\
\hline
\end{tabular}

$\mathrm{A}, \mathrm{AB}$ and $\mathrm{B}$ soil horizons. $\mathrm{M} 1: 10 \mathrm{kPa}-30 \mathrm{kPa}$; $\mathrm{M} 2: 10 \mathrm{kPa}-100 \mathrm{kPa}$; 3 : $10 \mathrm{kPa}-1500 \mathrm{kPa}$ depletion levels; CV \% - covariant; LSD- least significant different; ***-P $<0.001$. 
Table 06: Glucose concentrations of leaves, root absorption cells and respiratory organs of coconut seedlings under different soil physical and moisture stress in Andigama series

\begin{tabular}{llll}
\hline $\begin{array}{l}\text { Treatments depth and } \\
\text { moisture levels }\end{array}$ & Leaves & $\begin{array}{c}\text { Glucose concentration } \\
(\boldsymbol{\mu} \text { mol/g }) \\
\text { Absorption cells }\end{array}$ & Respiratory organs \\
\hline AM1 & $5.22 \pm 1.60$ & $16.4 \pm 0.96$ & $3.60 \pm 1.40$ \\
ABM1 & $4.31 \pm 0.30$ & $12.9 \pm 4.00$ & $3.50 \pm 0.70$ \\
BM1 & $3.03 \pm 0.80$ & $10.2 \pm 5.40$ & $2.90 \pm 0.50$ \\
AM2 & $6.40 \pm 0.30$ & $7.20 \pm 1.00$ & $2.50 \pm 0.70$ \\
ABM2 & $5.00 \pm 0.02$ & $3.80 \pm 1.70$ & $2.40 \pm 0.70$ \\
BM2 & $4.98 \pm 0.90$ & $1.20 \pm 0.30$ & $1.50 \pm 0.40$ \\
AM3 & $6.08 \pm 0.70$ & $3.90 \pm 0.60$ & $2.30 \pm 0.20$ \\
ABM3 & $4.90 \pm 0.80$ & $2.30 \pm 1.30$ & $2.30 \pm 0.20$ \\
BM3 & $5.19 \pm 0.92$ & $1.10 \pm 0.40$ & $1.78 \pm 0.90$ \\
Significance & $* *$ & $* * *$ & $*$ \\
CV \% & 16.56 & 33.10 & 29.57 \\
LSD & 1.420 & 3.510 & 1.280 \\
\hline
\end{tabular}

$\mathrm{A}, \mathrm{AB}$ and $\mathrm{B}$ soil horizons. $\mathrm{M} 1: 10 \mathrm{kPa}-30 \mathrm{kPa}$; $2: 10 \mathrm{kPa}-100 \mathrm{kPa}$; 3 : $10 \mathrm{kPa}-1500 \mathrm{kPa}$ depletion levels; $\mathrm{CV} \%$ - covariant; LSD- least significant different; ${ }^{-}$-p $<0.05 ;{ }^{*}$-P $<0.01 ; * * *$-P $<0.001$.

Table 07: Glucose concentration of leaves, root absorption cells and respiratory organs of coconut seedlings under different soil physical and moisture stress in Madampe series.

\begin{tabular}{|c|c|c|c|}
\hline \multirow[t]{2}{*}{$\begin{array}{l}\text { Treatments depth and } \\
\text { moisture levels }\end{array}$} & \multicolumn{2}{|c|}{$\begin{array}{c}\text { Glucose concentration } \\
\qquad(\mu \mathrm{mol} / \mathrm{g})\end{array}$} & \multirow[b]{2}{*}{ Respiratory organs } \\
\hline & Leaves & Absorption cells & \\
\hline AM1 & $7.40 \pm 2.20$ & $17.80 \pm 7.70$ & $4.00 \pm 1.80$ \\
\hline ABM1 & $7.40 \pm 1.00$ & $18.9 \pm 7.50$ & $1.80 \pm 1.20$ \\
\hline BM1 & $8.40 \pm 2.30$ & $20.0 \pm 8.60$ & $2.50 \pm 0.20$ \\
\hline AM2 & $0.29 \pm 0.08$ & $3.20 \pm 1.30$ & $2.40 \pm 0.50$ \\
\hline ABM2 & $0.47 \pm 0.20$ & $3.90 \pm 1.70$ & $1.50 \pm 0.30$ \\
\hline BM2 & $0.50 \pm 0.30$ & $5.30 \pm 3.50$ & $1.60 \pm 0.90$ \\
\hline AM3 & $0.30 \pm 0.10$ & $2.70 \pm 1.40$ & $4.40 \pm 0.40$ \\
\hline ABM3 & $0.50 \pm 0.50$ & $3.00 \pm 1.60$ & $2.00 \pm 0.10$ \\
\hline BM3 & $0.50 \pm 0.40$ & $3.80 \pm 1.70$ & $1.50 \pm 0.50$ \\
\hline Significance & $* * *$ & $* * *$ & $* *$ \\
\hline $\mathrm{CV} \%$ & 42.50 & 55.69 & 34.31 \\
\hline LSD & 2.040 & 8.350 & 1.420 \\
\hline
\end{tabular}

A, AB and B soil horizons. M1: $10 \mathrm{kPa}-30 \mathrm{kPa}$; $2: 10 \mathrm{kPa}-100 \mathrm{kPa}$; M3: $10 \mathrm{kPa}-1500 \mathrm{kPa}$ depletion levels; $\mathrm{CV} \%$ - covariant; LSD-least significant different; **-P $<0.01$; ***-P $<0.001$. 


\section{Glucose content in respiratory organs}

The glucose concentration of respiratory organs of both series was higher in A horizons at field capacity level compared to other horizons and also moisture levels. It is possible that oxygen concentration in the root-soil interface could influence the function of respiratory organs. Pierre and Alian, (1980) reported that ATPase activity and starch to glucose conversion rate in maize root tips can be changed by external oxygen concentration. Oxygen concentration in root soil interface regularly correlated with soil moisture content. He also reported that low oxygen concentration under stress conditions retard the function of respiratory system resulting in a decrease in glucose concentration in roots. Poor physical conditions of B horizon of Andigama series can retard the normal physiological activities of coconut roots resulting in a retardation of growth rate of coconut seedlings.

\section{Proline content}

Among the biochemical changes that take place in plants under water stress conditions, proline accumulation is the most widely reported in plants (Ali-Ahmad and Basha, 1998; Verbrugger and Hermans, 2008). Bodapati et al., (1992) reported that proline accumulation in plant tissue can be used as an indicator of drought stress. Wiliam and Sharon (1981) reported that proline accumulation was greater and most prolonged in wilted leaves with higher sugar and starch contents. Water stress enhanced accumulation of proteins, free amino acids, and soluble sugars in the peanut plants (Ali-Ahmad and Basha, 1998).

\section{Proline content in leaves}

Pairwise comparison with LSD test revealed that proline concentration in leaves of coconut seedlings grown in Madampe series was not significantly different with respect to depth and moisture levels (Table 09). However, the proline concentration in leaves $(\mathrm{P}<0.05)$ in Andigama series changed significantly with depth and moisture levels (Table 08). Proline content in leaves decreased in Madampe series (Table 09) with depth and moisture levels, whilist it increased in Andigama series (Table 08). Proline accumulation increased with water stress and it remained constant in leaves of spinach, in severe stress conditions (Hvang and Cavalieri, 1979). In contrast, proline accumulation in plant tissues beneficiary affects on flowering (Mattioli et. al., 2009). Proline concentration of forage grasses was 20 times greater in stressed compared to well watered plants grown in green house (Barker et al., 1993).

A proline level in leaves was lower than absorption cells in Madampe series. Results also revealed that proline accumulation in leaves was higher in A horizon of Madampe series and B horizon of Andigama series respectively. Proline accumulation in tissues of coconut seedlings was sensitive to the soil physical stress as well as to the water stress of soil. However, Bodapati et al., (1992) reported that the higher vapor pressure deficits during stress also resulted in higher solute contents and this response may be more closely related to leaf water potential. Furthermore, proline accumulation in leaves of Madampe series was very low compared to that of in Andigama series.

\section{Proline content in absorption cells}

Pairwise comparison with LSD test revealed that proline concentration in absorption cells in Madampe series did not show any significant difference with respect to depth and moisture (Table 09). However, the proline concentration in absorption cells in Andigama series was significantly $(<0.001)$ higher with increasing depth and moisture levels (Table 08). Proline content in absorption cells in Madampe series decreased with depth and moisture levels, whilist it increased in Andigama series. The proline level of absorption cells was higher than that of leaves in Madampe series (Tables 08 and 09). Results also revealed that proline accumulation in absorption cells was quite noticeable in A horizon of Madampe series and B 
horizon of Andigama series, respectively.

\section{Proline content in respiratory organs}

Proline content in respiratory organs deferred significantly $(\mathrm{P}<0.05)$ in both series with respect to depth and moisture levels of soils (Tables 08 and 09). The proline content decreased with depth in Madampe series and increased with depth of Andigama series. Results also showed that proline content in respiratory organs of coconut seedlings was more sensitive to soil physical stress than the water stress of soil. Yoseph (1980) reported that free proline accumulation in lemon trees under soil moisture stress had a linear relationship with noon xylem pressure potential. Xylem pressure potential is regarded as a very good measure of water stress, but is very sensitive to the momentary water balance of the tree, exhibiting a diurnal curve as well as brief fluctuations
(Levy and Kaufmann, 1976). Barnett and Naylor (1976) also reported that proline accumulation positively correlated with water stress and water stress leads to blockage of synthesis of some amino acid at one or more points in the metabolic pathway. Hence, metabolic interferences of this kind could retard the growth and development of coconut seedlings under water soil physical stress condition. Yoesph (1980), further explained that free proline concentration may provide an indicator that integrates the effect of water stress, or similar environmental stress which may lower xylem pressure potential such as low temperature, nutrient deficiencies, or high salinity over a short period of time and is sensitive enough to change in xylem pressure potential within one or two days, and may provide a tool for comparing different irrigation or cultural regimes.

Table 08: Proline concentrations of leaves, root absorption cells and respiratory organs of coconut seedlings under different soil physical and moisture stress in Andigama series

\begin{tabular}{llll}
\hline $\begin{array}{l}\text { Treatments depth and } \\
\text { moisture levels }\end{array}$ & Leaves & $\begin{array}{c}\text { Proline concentration } \\
(\boldsymbol{\mu} \text { mol/g }) \\
\text { Absorption cells }\end{array}$ & Respiratory organs \\
\hline AM1 & $0.96 \pm 0.20$ & $1.02 \pm 0.03$ & $1.60 \pm 0.40$ \\
ABM1 & $1.30 \pm 0.07$ & $1.10 \pm 0.73$ & $2.60 \pm 0.05$ \\
BM1 & $2.45 \pm 1.02$ & $2.23 \pm 0.97$ & $4.80 \pm 0.60$ \\
AM2 & $0.85 \pm 0.33$ & $1.07 \pm 0.41$ & $1.24 \pm 0.34$ \\
ABM2 & $1.90 \pm 0.30$ & $1.85 \pm 0.60$ & $2.96 \pm 0.30$ \\
BM2 & $2.40 \pm 0.61$ & $3.30 \pm 0.12$ & $3.18 \pm 1.70$ \\
AM3 & $2.40 \pm 0.61$ & $1.33 \pm 0.23$ & $1.50 \pm 0.98$ \\
ABM3 & $1.60 \pm 0.80$ & $2.40 \pm 0.53$ & $2.40 \pm 1.60$ \\
BM3 & $1.73 \pm 0.90$ & $3.54 \pm 1.10$ & $3.60 \pm 1.80$ \\
Significance & $*$ & $* * *$ & $*$ \\
CV \% & 34.84 & 29.33 & 41.5 \\
LSD & 1.056 & 0.999 & 1.89
\end{tabular}

$\mathrm{A}, \mathrm{AB}$ and $\mathrm{B}$ soil horizons. $\mathrm{M} 1: 10 \mathrm{kPa}-30 \mathrm{kPa}$; 2 : $10 \mathrm{kPa}-100 \mathrm{kPa}$; $\mathrm{M} 3: 10 \mathrm{kPa}-1500 \mathrm{kPa}$ bar depletion levels; CV \% - covariant; LSD-least significant different; *-p $<0.05 ;{ }^{*} * *_{-} \mathrm{P}<0.001$. 
Overall evaluation of results of biochemical studies of coconut seedlings in respect to soil physical and moisture stress revealed that ATPase activity negatively correlated with soil physical stress and moisture stress. The highest ATPase activity was observed when the moisture content was at field capacity level in A horizon of Andigama and B horizon of Madampe, while the lowest was observed in the higher stress level $(100 \mathrm{kPa}$ to $1500 \mathrm{kPa}$ moisture level) in B horizon of Andigama series and A horizonof Madampe series. Starch accumulation in leaves and absorption cells also positively correlated with soil conditions and moisture levels. This could be attributing to optimum photosynthesis under favorable conditions. However at higher soil physical and water stress (viz. B horizon of Andigama series and at the $100 \mathrm{kPa}$ to $1500 \mathrm{kPa}$ moisture level) an increased accumulation of starch was observed. This could be due to a retardation of metabolic activities under stress. In addition, starch content was found to be more sensitive to soil physical stress than to soil moisture stress. Evaluation of results of biochemical studies also suggested that function of respiratory organs could depend on aeration capacity of soils. Above results clearly showed that A horizons of both series increase the function of respiratory organs compared to other horizons of both series increase the function of respiratory organs compared to other horizons. Drew, (1988) reported that low oxygen concentrations in the root environment strongly inhibits ion uptake and transport to the shoot. This explains the growth retardation of coconut seedlings grown in A horizon of Madampe series and B horizon of Andigama series.

Table 09: Proline concentration of leaves, root absorption cells and respiratory organs of coconut seedlings under different soil physical and moisture stress in Madampe series.

\begin{tabular}{llll}
$\begin{array}{l}\text { Treatments depth and } \\
\text { moisture levels }\end{array}$ & Leaves & $\begin{array}{c}\text { Proline concentration } \\
(\boldsymbol{\mu} \text { mol/g }) \\
\text { Absorption cells }\end{array}$ & Respiratory organs \\
\hline AM1 & $0.62 \pm 0.30$ & $2.98 \pm 0.90$ & $5.40 \pm 1.10$ \\
ABM1 & $0.39 \pm 0.20$ & $1.50 \pm 0.50$ & $3.40 \pm 3.40$ \\
BM1 & $0.35 \pm 0.40$ & $1.40 \pm 0.50$ & $3.30 \pm 1.30$ \\
AM2 & $0.36 \pm 0.20$ & $3.07 \pm 1.60$ & $3.40 \pm 0.80$ \\
ABM2 & $0.38 \pm 0.12$ & $1.70 \pm 1.00$ & $5.10 \pm 4.70$ \\
BM2 & $0.34 \pm 0.04$ & $1.70 \pm 0.90$ & $3.00 \pm 0.90$ \\
AM3 & $0.66 \pm 0.81$ & $4.00 \pm 1.30$ & $1.80 \pm 0.30$ \\
ABM3 & $0.53 \pm 0.43$ & $3.00 \pm 1.30$ & $2.50 \pm 0.30$ \\
BM3 & $0.53 \pm 0.38$ & $1.95 \pm 0.13$ & $0.80 \pm 0.30$ \\
Significance & $\mathrm{NS}$ & $\mathrm{NS}$ & $*$ \\
CV \% & 34.02 & 27.20 & 2.80 \\
LSD & 1.056 & 0.999 & 1.89 \\
\hline
\end{tabular}

A, AB and B soil horizons. M1: $10 \mathrm{kPa}-30 \mathrm{kPa}$; M2: $10 \mathrm{kPa}-100 \mathrm{kPa} ; \mathrm{M} 3: 10 \mathrm{kPa}-1500 \mathrm{kPa}$ depletion levels; $\mathrm{CV} \%$ - covariant; LSD-least significant different; ${ }^{*}$-p $<0.05$. 
Glucose content in live tissues of coconut seedling was more sensitive to moisture levels of soil compared to soil physical stress. Results also conclusively showed that glucose concentration was negatively correlated with soil physical and moisture stress. A higher glucose concentration in live tissue of coconut seedlings was observed in A and B horizons of Andigama and Madampe series respectively. Glucose concentration in respiratory organs was higher in A horizons of both series. Glucose concentration is more sensitive to water stress compared to the soil physical stress (Tables 06 and 07). Yoav and Amram (1991) reported that between one third and two third of all the carbohydrate translocated to the roots are used in respiration. According to the above concept, proper soil conditions can make available sufficient minerals in the rootsoil interface of coconut seedlings. Carbohydrate in coconut seedlings would be converted to simple sugar, which could then be utilized in root respiration. The increases activity of ATPase resulting absorption of mineral nutrient from dynamic pool and lead to better performance on the growth and development of coconut seedlings.

Proline content in coconut seedlings was negatively correlated with soil stress. It was more sensitive to soil physical stress than to water stress. Proline accumulation in leaves and absorption cells of coconut seedling grown in A horizon of Madampe and B horizon of
Andigama series suggest that those horizons are under soil physical and water stress compared to other horizons. Such stress conditions naturally would tend to retard the growth and development of coconut seedlings. However, crops need proline accumulations in some extend to induce their reproduction stage (Mattioli et. al., 2009). Adsorption of appropriate cultural practices is one of the ways of rectifying drawback caused by stress conditions.

\section{CONCLUSIONS}

It is evident from the results that soil compaction restricted the available water fraction and aeration status in soil resulted in retardation of biochemical aspect of coconut seedlings. Optimum aeration and available water status of soil promote the ATPase activity and starch conversion to glucose in different parts of coconut seedlings resulted high growth rate of coconut seedlings. However, high aeration status of soil promote the biochemical activity of respiratory organs, while, high proline and starch accumulation was observed under soil physical and water stress conditions.

\section{ACKNOWLEDGEMENT}

Financial Assistance provided by the Council for Agricultural Research Policy (CARP), Sri Lanka (Research grant number 12/175/149) is gratefully acknowledged.

\section{REFERENCES}

Albrecht, O. Jungk. (1991). Dynamics of nutrient movement at the soil- root interface. In plant roots (Eds.Yoav Waisel A. and Uzi Kafkafi). Publ.Marcel dekker Inc. New York, pp. 455481.

Ali-Ahmad, M. and S. M. Bash (1998). Effect of water stress on composition of peanut leaves. Peanut Science: 25: 31-34.

Arkin and Taylor (1981). Modifying the root environment to reduce crop stress.Publ. American Society of Agricultural Engineers. pp. 13. 
Atsushi, O., K. Choji and Y. Akira (2005). Sugar accumulation along the seminal root axis, as affected by osmotic stress in maize: A possible physiological basis for plastic lateral root development. Plant production science. 8: 173-180.

Barber, S. A. (1984). Soil nutrient bioavailability: A mechanistic approach. Publ. John Wiilry \& Sons. New York, pp. 55-89.

Barker, D. J., C. Y. Sullivan and L. S. Moser (1993). Water deficit effects on osmotic potential, cell wall elasticity and proline in five forage grasses. Agro.J.85:270-275.

Barnett, R. A and A. W. Naylor (1976). Amino acid and protein metabolism in Beruda grass during water stress. Pl.Physiol. 41: 1222-1230.

Bates, L. S. (1973). Rapid determination of free proline for water- stress studies. Plant and Soil 39: 205-207.

Bell, J. P. (1987). Neutron probe practice. Institute of Hydrology, Wallingford, U. K. $3^{\text {rd }}$ ed. Report 19.

Bert, P. S., G. Otto., K. C. E. E. S. Monika, K. Ander and K. J. C Pieter (1981). Transport of $\mathrm{Mg}^{+2}$ and $\mathrm{Ca}^{+2}$ and $\mathrm{Mg}^{+2}$ stimulated adenosine triphophatase activity in Oat roots as affected by mineral nutrition. Physiol. Plant 52: 115-123.

Bodapati, P. N., Donald, A. and Lesile G. P. (1992).Variability in proline accumilation ability of barley (Hordeum vulgare $L$ ) cultivars induced by vapor pressure deficit. Plant Physiol. 98: 716-722.

Bradford, J. M. (1986). Penetrability. In Method of Soil Analysis. Part 1. $2^{\text {nd }}$ Ed. ASA Monodraph 9. Ed. A. Klute. Am. Soc. Agron, Wisconsin, USA. Deanna. pp 463-472.

Child, R. (1974). Coconut-second edition. Logman group limited publishers. pp. 40-41.

Davis, T. A. (1968). A study on the respiratory organs of Cocos nucifera Linn Ceylon Cocos, Quart. 3: 116-136.

Dietz, K. J., N. Tavakoli, T. Mimura, S. S. Sharma, G. C. Harris, A. N. Chanrdonnens and Golldack, D. (2001). Significance of the V-type ATPase for the adaptation to stressful growth conditions and its regulation on the molecular and biochemical level. Journal of Experimental botany, 52, pp. 1969-1980.

Drew, M. C. (1988).Effect of fooding and oxygen deficiency on plant mineral nutrient.Vol.3 (A Lauchli and P.B. Tinker eds.). Praeger, New York. pp.115-159.

Dubois, M., K. A., J. K. Gilles, P. A. Hamilton, Rebers and F. Smith (1956). Colourimetric method for determination of sugar and related substance. Anal.Chem. 28: 350-356.

Fisher, J. D., H. Dale and. T. K. Hodges (1970). Correlation between ion fluxes and ion-stimulated Adenosine Triphosphate activity of plant roots. Plant physiol. 46: 812-814.

Gluthe, K. F. (1968). Soil aeration and its role for plants. Publ. CRC Press, Inc. Baca Raton, PP 17.

Hendrik Poorter, Adrie van Werf, Owen K. Atkin and hans lambers (1991). Respiratory energy requirements of roots vary with the potential growth rate of plant species. Physiolo.Plant. 83: 469-475.

Hideaki Matsumoto, Minobu Kasai and Yoko Yamamoto (1993). Reconstitution of plasma membrane ATPase from mature cucumber roots. Soil Sci.Nutri.39: 547-556.

Hvang, A. H. C. and A. J. Cavalierri (1979). Prolone oxidase and water stress induced proline accumulation in spinach leaves. Plant.Physiol.63: 531-535.

Klute, A. (1986). Water retention. In method of soil analysis part 1. Second Ed. ASA Monograph 9. Ed. A. Klute. Am. Soc. Agron.,Wisconsin, USA. pp. 425-441. 
Lambers, H. (1985). Respiration in intact plants and tissues: its regulation and dependence on environmental factors, metabolism and invaded organisms. In Encyclopedia of plant physiology, New Series (R. Douce and D.A. Day Eds.) Springer-verlag Berlin. pp.418473.

Lambers, H., D. W. Adrie-van and K. Henk (1991). Respiratory patterns in roots in relation to their functioning. In plant roots (Eds. Yoav waisel Amram Ehhel and Uzi Kafkafi). Publ. Marcel Dekker Inc.New York, pp.229-265.

Levy, Y. and M. R. Kaufmann (1976). Cycling of leaf conductance in citrus exposed to natural and controlled environment.Can.J.Bot.54: 2215-2218.

Liang, J., J. Zharg, L.Y.S. Chan, M. H. Wong (1999). Can differences in root responses to soil drying and compaction explain differences in performance of tree growing landfull sites? Tree physiology 19: 619-624.

Lindeman, W. (1958). Observation on the behavior of phosphate compounds in chlorella at the transition beem dark to night. Proc.11nd Int.Conf.of UN on the peaceful use of Atomic Energy.24: 8-15.

Lowry, O. H., N. J. Rosebrough, A. L. Farr and R. J. Randall (1951). Protein measurement with the folin phenol reagent.J.Biol.Chem.193: 265-275.

Marianne, S., L. Tommas and K. Anders (1985). Comparison of K, Mg, ATPase in purified plasmalemma from wheat and oat-Substrate specificities and effect of $\mathrm{PH}$ temperature and inhibitors. Physiol.Plant.65: 27-32.

Martine, D., B. Renaud, P. Alain, and R. Phillpe (1992). Increased fatty acid B-oxidation after glucose starvation in maize root tips. Plant Physiol. 99: 595-600.

Mattioli, R., P. Costantino and M. Trovato (2009). Proline accumulation of plants. Landes Bioscience 4: 1016-1018.

Pierre, H. S. and P. P. Alian (1980). Soluble sugars, respiration, and energy charge during aging of excised maize root tips. Plant physiol.66:516-519.

Raymond, P. H. and A. Pradet (1980). Stabilization of adenine nucleotide ratio at various values by an oxygen limitation of respiration in germination lettuce (Lactua sativa) seeds. Biochem J.190:39-44.

Roberto, M., C. Paolo and T. Maurizio (2009). Proline accumulation in plants.Landes Bioscience. 4(11): 1016-1018.

Rosa, M., C. Prado, R. Interdonato, J. A. Gonzalez, M. Hilal, and F. E. Prado (2009). Soluble sugars-Metabolism, sensing and abiotic stress. Plant Signal Behav. 4: 388-393.

Somasiri, L. L. W., N. Nadarajah, L. Amarasiri and H. A. Gunathilaka (1994). Land suitability assessment of coconut survey area in the coconut triangle (eds. C. R. panabokke and Mahindapala, R.). Publ. Coconut Reasearch Institute, Sri Lanka.

Verbruggen, N. and Hermans, C. (2008). Proline accumulation in plants. Epub. 35: 753-759.

Vidhana Arachchi L. P. (2000). Soil Physical constraints and their effect on morphlogcal characters of coconut (Cocos nucifera L.) roots. Asian and Pacific Coconut Community, Coconut Research and Development (CORD), 16: 14-33.

Vidhana Arachchi, L. P. (2009). Effect of deep ploughing on water status of highly and less compacted soils for coconut (Cocos nucifera L.) production in Sri Lanka. Soil \& Tillage Research. 103:350-355. 
William, R. F. (1948). The effect of phosphorus supply on the rate of intake of phosphorus and nitrogen upon certain aspects of phosphorus metabolism in gramineous plants. Aust.J.Sci. Res.1:333-361.

William, V. D. and S. E. Sharon (1981). Isolation, assay, biosynthesis, metabolism, uptake and translocation and function of proline in plant cells and tissue. The botanical review

Witold, S. and P. Arazyna (1992). The influence of soil oxygen availability on yield and nutrient uptake N, P, K, C, Mg, Na by winter rye (Secale cereal) plant and soil. 143:267-274.

Yoav, W. and E. Amram (1991). Multifiform behavior of various constituents of one root system. In plant roots (Eds.Yoav Waisel A. and Uzi kafkafi).Publ.Marcel Dekker Inc. New York. pp. 39-52.

Yoseph, L. (1980). Field determination of free proline accumulation and water- stress in lemon trees. Hort.Sci.15:302-303. 